\title{
Telecommunication Universal Access and Services:
}

\section{Theory and Practice}

\section{Sigit Haryadi}

Institut Teknologi Bandung March

2018

Paper DOI10.17605/OSF.IO/D8EGP

Citation: Haryadi, S. (2018, March 8). Telecommunication Universal Access and Services: Theory and Practice. Retrieved from osf.io/preprints/inarxiv/d8egp

\section{Abstract}

This paper outlines the ITU-D theory of Telecommunication Universal Access, and comes with examples of practice, especially in Indonesia.

\section{The Term and definitions of Telecommunication Universal Access and Service}

The term of universal access is used in a wide variety of contexts to describe or demonstrate objectives and policies that governments implement to ensure that all their citizens have access to the benefits of modern economic life, in the contexts of health care (especially for the prevention and treatment of HIV/AIDS), primary education, electricity and energy, and water and sanitation, as well as Information and Communication Technologies (ICTs).

Definitions in regards to telecommunication communications services:

- Universal access (UA) is when everyone can access the service somewhere, at a public place, thus also called public, community or shared access.

- Universal service (US) or Universal Service Obligation (USO) describes when every individual or household can have service, using it privately, either at home or increasingly carried with the individual through wireless devices. Note: the goal of full US would be too ambitious at present in a developing country, because the services must be affordable as well as available, then the Goals may relate to the proportion of the population that can afford private service (i.e., subscriber penetration targets).

The three hallmarks of UA and US are:

- Availability: the service is available to inhabited parts of the country through public, community, shared or personal devices; 
- Accessibility: all citizens can use the service, regardless of location, gender, disabilities and other personal characteristics; and

- Affordability: the service is affordable to all citizens.

\section{Scope of Telecommunication Universal Access and Service}

\subsection{Origins of Telecommunication universal service}

Historically, the term and concept of US (Universal Service) or USO (Universal Service

Obligation) existed before UA (Universal Access). In detail, USO for telephone service, first mentioned in the 1934 Communications Act of the United States, describes the concept of affordability of telephone services, as well as its universal availability for households desiring that service. Otherwise, UA (universal Access) is focused on public, community or shared access to telecommunications.

\subsection{Evolution of Universal Service Obligation}

Figure: Steps in developing communications capability

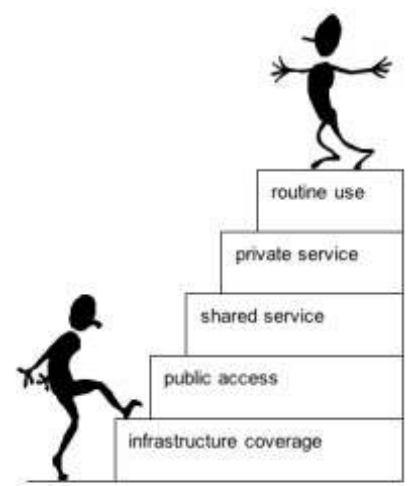

Source: ITU-infoDev ICT Regulation Toolkit - UA Module

Figure: Possible rising aspirations for ICTs

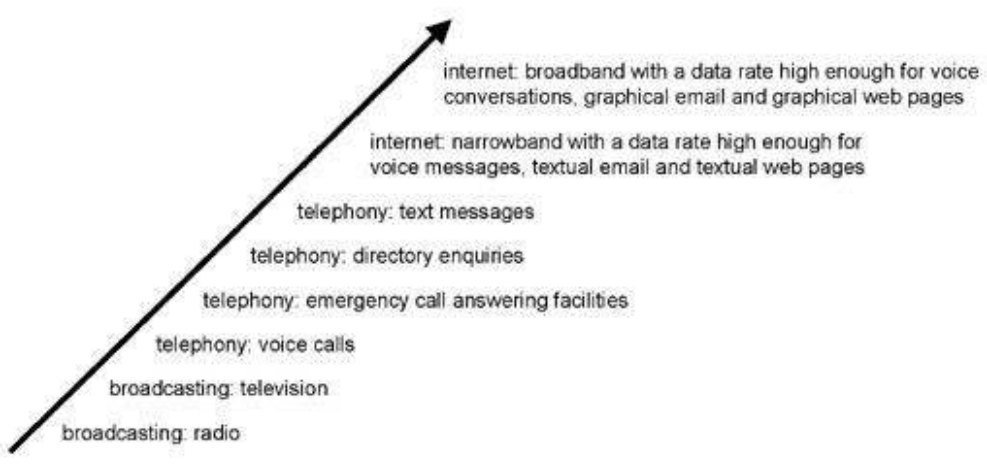

Source: ITU-infoDev ICT Regulation Toolkit - UAS Module

The concepts of UA and US are applicable to the following ICT services:

1. Telephony (voice calls and text messages), offering one-to-one communication as well as content distribution to a wider group. Text messages are often also significant for 
UAS, because the affordability of text messages outweighs the inconvenience of using mobile phone keypads and displays.

2. Narrowband and broadband Internet, providing e-mail, live-chats, web-browsing, content distribution, Voice over IP (VoIP) and IP Television (IPTV), among many other applications and services. Many countries also want UA to the Internet however his requires higher levels of skill and education than with broadcasting or telephony. Therefore, accessibility through instruction and assistance and content that is useful and appealing is particularly important.

3. Radio and television broadcasting. While broadcasting has traditionally not been a part of UAS policies, it is increasingly being considered, due to the convergence of technologies and triple-play offers by service providers (e.g., cable TV operator's also providing telephone and Internet services). UAS policies exploring the inclusion of broadcasting are emerging. This is especially the case in countries that have adopted a multi-sector regulator overseeing both telecommunications and broadcasting

\subsection{Universal access and service targets}

- Universal access and service (UAS) measures are usually targeted at rural areas that are unserved or underserved, and especially low-population density areas where provision of services is not viable. But UAS targets can also be focused on very poor urban areas in large metropolitan cities, including slums.

- Developing countries typically set the following universal access (UA) targets:

- A public phone for a certain size of community (e.g., for all communities larger than 2000 inhabitants);

- A limited walking distance to a public phone (e.g., $5 \mathrm{~km}$ for communities too small to have their own public phone);

- An Internet POP in districts centers, provincial capitals or towns above a certain size (e.g., above 20,000 inhabitants) that provides either high-speed or broadband capacity; and

- A public access Internet center accompanying the Internet POP

\subsection{Practice Examples of the Scope of Universal Access and Service}

Here are some practical examples of Scope of Universal Access and Service: 
1) In developing countries, the scope of Universal Service since the 1990s, target of the Universal Service Obligation for telephony in urban areas and setting Universal Access targets for rural areas. And, in the 2000s, USO is about both telephony and low rates Internet.

2) The Europe Union:

a. 2002: Universal Service Directive a requirement that the scope of universal service (US) obligations be reviewed every three years. The scope of US in the EU was originally confined to telephony at a fixed location for voice calls, fax calls and data calls (for narrowband Internet using dial-up). The first review of the scope took place in 2006. Two services, mobile telephony and broadband Internet were new candidates for addition to the US's scope.

b. In 2008 , broadband Internet is defined by the ITU and OECD as always on service with download speeds equal or faster than $256 \mathrm{Kbps}$.

3) In affluent countries, the scope of Universal Access and Service has changed from telephone service to the Broadband Universal Service.

a. Switzerland was the first country in the world to provide broadband universal service with download/upload $600 / 100 \mathrm{Kbit} / \mathrm{s}$ data speed to its citizens in January 2008.

b. Finland was the first country in the world to establish broadband universal service, the $1 \mathrm{Mbit}$ Internet connection, albeit at a basic speed, as a general right of citizens.

c. Spain guarantees $1 \mathrm{Mbit} / \mathrm{s}$.

d. United Kingdom: a universal service for every home in Britain of $2 \mathrm{Mbit} / \mathrm{s}$ in 2012. In 2015, the UK announced a universal service obligation of $10 \mathrm{Mbit} / \mathrm{s}$ in 2020 for every home in Britain, however as of January 2017 this has still to ratify into an Act.

e. Canada, in 2016, announced a universal service obligation of 50Mbit/s for their huge country by 2021 .

f. Belgium has a universal service obligation of $1000 \mathrm{Mbit} / \mathrm{s}$ for $50 \%$ of the population by 2020 .

g. Sweden has set a target of $100 \mathrm{Mbit} / \mathrm{s}$ for $95 \%$ of its population by 2020 , and a USO of $1000 \mathrm{Mbit} / \mathrm{s}$ to $98 \%$ of the population $(100 \mathrm{Mbit} / \mathrm{s}$ to the next $1.9 \%$ and $30 \mathrm{Mbit} / \mathrm{s}$ to the final $0.1 \%$ ) by 2025 . 
h. Taiwan, In 2007, the National Communications Commission (NCC) set up the goal to offer Internet access services with a speed of 2 megabytes per second (Mbps)to every village in Taiwan. More than fifty remote villages which did not have broadband service are able to access broadband. The NCC aimed to further broadband access to more rural areas in 2011.

i. Japan, telecommunications carriers that provide universal service must endeavor to provide that service in an appropriate, fair, and stable manner. These services include subscriber line access, public telephone service and emergency calls service.

j. United States, 2008: The Federal Communications Commission (FCC) of the United States defines broadband as $768 \mathrm{kbps}$ or faster.

\section{Rationale for a Universal Access Policy}

a) ICTs are social and economic enablers. ICTs are increasingly used in all sectors of economies. In many regions, economic activity is shifting away from agriculture and industry to services sectors, and towards the new information economy and society. The ICT sector is considered to be a significant engine of growth for economies.

b) Supply and demand increases the importance of UAS policy. Interestingly, the increased supply of ICTs through rapid technological developments and base of pyramid marketing, actually fuels the requirement for UA. Mobile phones, not too long ago considered luxury items and out of reach for most, are now providing the main access to voice service for the majority of people in many countries, making it more urgent that the population without access be provided with access to phone service. Similarly, for large parts of populations work and life without the Internet is unthinkable, and ever more megabyte-rich applications require increased broadband development. The more ICTs are used, the more there is a dependence upon them, which in turn makes it more essential that all citizens have access to ICTs.

c) Market gaps can remain in place. While it has been demonstrated that market forces, after liberalization and sector reform, have had the greatest impact on improvement of UAS in many developing countries, for various reasons market gaps can remain in place. Some countries, for example, have exceptionally challenging geographic characteristics combined with extremely low population densities (e.g., Mongolia and Botswana) or isolation (e.g., many islands in the Pacific region) or extreme poverty, which make UAS tremendously challenging. In other countries, the market might be 
able to achieve UAS, but the timeframe in which this could be obtained, might be considered too long.

d) Monitoring UAS and updating it. Constant change in technology, services, and pervasiveness of various ICT services makes it necessary that the status of UAS should be monitored and policies continue to be updated and developed. Also, there are countries where the market can achieve UAS, but there is a need for public oversight to confirm that it has been achieved, to improve regulation, and to continually review the concept of what is considered UAS.

\section{International developments}

- The main international initiatives related to universal access and service (UAS) are the World Summit on the Information Society (WSIS) objectives, and the Millennium Development Goals (MDG). The WSIS objectives raised the political profile of ICT development and recognized that access to communications is necessary to achieve basic human rights. The WSIS objectives also recognize the need for special action (i.e., a UA policy and its implementation) to provide such access to all, especially disadvantaged groups. They also prompted commitments to provide a large amount of funding for connecting communities globally by 2015 .

- The Millennium Development Goals (MDGs), include a global partnership for development whose target is to provide citizens with all the benefits of new technologies, especially information and communications, in cooperation with the private sector. There is some debate around whether and how ICT deployment assists in reaching the MDGs, but the following points seem clear:

- ICTs can help in implementing many initiatives that contribute directly to reaching development goals even when they do not necessarily contribute directly themselves;

- ICTs have impacts that depend on the technical, economic, administrative and social environment, so general assessments of their contributions without considering the local context are difficult; and

- ICTs are increasingly understood to be complementary to other development imperatives and not to be traded off against them. 


\section{Integration with Other National Programs}

- Universal access and service (UAS) policies do not exist in isolation, they are relevant to education, e-government, electricity, and micro-finance and e-banking, among others. However, overarching national policy on ICT development should provide overall direction and facilitate and define the inter-linkages among the various sectors, policies, stakeholders and initiatives.

- ICTs are especially important for education, but voice alone is a limited medium, telephony and radio broadcasting are not enough in the context of dynamic education. In consequence, universal access (UA) generally means "universal Internet access", and increasingly, "universal broadband Internet access". Many UAS policies include the provision of Internet access to schools, often partially paid for by Universal Access and Service Funds (UASFs). However, while Internet access for schools might be paid for by UASFs, making effective use of the access is the responsibility of the school, the ministry of education and others. The task of training teachers and providing enough useful and appealing content is particularly significant.

- E-government is the use of ICTs to make government more responsive, efficient, effective, and transparent. The conditions within a country, including communications infrastructure and public access, transparency of governance, but also government capacity and public literacy, affect what is worth attempting in e-government.

- Though electricity is essential for telecommunications, in some developing countries telecommunications are often more widespread or more reliable than the main electricity supply; network operators provide their own power generators and their customers find unorthodox ways of recharging equipment, e.g., through car batteries. Important benefits could be gained by coordinating the provision of telecommunications with the provision of the main electricity supply. Telecommunications networks would be easier to operate and use and could share physical infrastructure with electricity networks. While it is a highly desirable practice, this co-ordination might be difficult to achieve. However, this absence does not need to prevent telecommunications provision in places that do not yet have the main electricity supply.

- Financial services that deal with small sums of money (micro-finance) are widely believed to help people escape from poverty, for example, the Grameen Village Phone programmed, provided women with loans to buy phones, sell phone calls, make profits 
and repay the loans. E-banking uses ICTs to make micro-finance available to more people in new, less expensive ways. These initiatives raise regulatory challenges of their own, separate from those of telecommunications; customers must be protected against fraud but regulation must not prevent the development of valuable and trustworthy services.

\section{Universal Access \& Service in Indonesia 6.1. The Regulation and Policy Norma:}

1) Peraturan Menkominfo Nomor: 15/Per/M.Kominfo/9/2005 on the Tariff Implementation Guidelines for Non-Tax State Revenues from the Universal Service Obligation Service Obligation Contributions

2) Peraturan Menkominfo Nomor: 11/Per/M.Kominfo/4/2007 on the Provision of Universal Telecommunication Service Obligations

3) Peraturan Menteri Kominfo No. 38/Per/M.Kominfo/09/2007 Tentang Change of the Provision of Universal Telecommunication Service Obligations

4) Peraturan Menteri Kominfo Nomor: 05 /PER/M.KOMINFO/2/2007 on the Tariff Implementation Guidelines for Non-Tax State Revenue from Contribution of Universal Telecommunication Service Obligation

5) Permenkominfo No. 26/Per/M.Kominfo/07/2008 Tentang change of the Tariff Implementation Guidelines for Non-Tax State Revenue from Contribution of Universal Telecommunication Service Obligation

6) Peraturan Menkominfo Nomor: 32/Per/M.Kominfo/10/2008 tentang on the Universal Service Obligation

7) Peraturan Menteri Kominfo No. 48/Per/M.Kominfo/11/2009 Tentang Provision of Internet Access Services in the Universal Telecommunication Service Area of the Internet District

8) Peraturan Menteri Komunikasi Dan Informatika Nomor : 03 /PER/M.KOMINFO/ 02 12010 Tentang Change of the Universal Service Obligation

9) Peraturan Menteri Komunikasi Dan Informatika Nomor : 19/Per/M.Kominfo/12/2010 change of Provision of Internet Access Services in the Universal Telecommunication Service Area of the Internet District

10) Peraturan Menteri Komunikasi Dan Informatika Nomor 
20/Per/M.Kominfo/12/2010 on Management Information System and Monitoring of 7. Sub-district Internet Service

11) Peraturan Menteri Komunikasi Dan Informatika Nomor

:21/PER/M.KOMINFO/12/2010 on the Provision of the Internet Exchange for Internet Services in the Universal Telecommunication Service Area of the Internet District

\subsection{Implementation}

The implementation of Universal Service Obligation in Indonesia is by providing liabilities to all telecommunications operators and providers to pay a non-tax obligation of $0.75 \%$ of their gross revenue annually. Non-tax earned from the telecommunications sector in the last 4 years is as follows $2013=11.5$ trillion rupiah; $2014=10.71$ trillion rupiah; $2015=12.38$ trillion rupiah; and $2016=14$ trillion rupiah.

\subsection{Program - Program Universal Service Obligation}

Non-tax revenues earned by the government are used to run Universal Access Obligation programs, which currently consists of two programs, namely infrastructure programs and ecosystem programs.

\subsection{Update Desember 2020 PERBANDINGAN KEBIJAKAN AKSES INTERNET DI DAERAH USO DI NEGARA LAIN BIDANG TIK}

\subsubsection{Australia}

Pemerintah Australia membagi dua area besar untuk implementasi USO, yaitu:

a. The greater Green Triangle yaitu Barat-daya Victoriadan Australia Tenggara termasuk Central Goldfields dan Greater Bendigo.

b. New South Wales Tenggara dan Queensland.

Standar layanan (Standard Telephony Service/STS) wajib disediakan oleh semua operator dan layanan yang ditetapkan dalam USO.

Sejak 2012, Australia mendirikan badan Telecommunications Universal Service Management Agency (TUSMA) untuk mengelola dana USO dalam rangka mendeliver layanan universal dan menelurkan ide-ide kebijakan publik di bidang telekomunikasi. Badan ini bekerja sampai tahun 2015 dan fungsinya digantikan oleh Department of Communications and the Arts sebagai agen tunggal penanggung jawab untuk kebijakan dan implementasi mengenai masalah layanan universal telekomunikasi. 
Skema pendanaannya adalah suatu operator telekomunikasi yang memenuhi syarat yaitu revenue \$ 25 juta, harus menyisihkan pendapatannya kepada Australian Communications and MediaAuthority (the ACMA). Kontribusinya adalah proporsional untuk setiap operator yang perhitungan tarifnya ditentukan oleh formula penentuan retribusi 2015 sesuai undang-undang perlindungan dan layanan pelanggan telekomunikasi (Telecommunication Consumer Protection and Service Standards ACT).

\subsubsection{Malaysia}

Di Malaysia, USO ditetapkan pada Communications and Multimedia Act 1998, dibawah otoritas menteri Komunikasi dan Multimedia, yaitu menyediakan layanan jaringan yang luas dan aplikasi layanan lainnya di seluruh Malaysia serta pembangunan fasilitas jaringan ke pelosok area atau komunitas tertentu yang belum terlayani dengan penuh.

Untuk mendukung layanan ini, pemerintah Malaysia menetapkan suatu pendanaan yang disebut Universal Service Provision Fund (USP Fund) yang dikelola oleh Malaysian Communications and Multimedia Commission. Pendaan tersebut berasal dari kutipan $6 \%$ dari weighted revenue operator telekomunikasi yang dihitung sebagai kontribusi USP. USP didesain untuk menjembatani digital divide di area yang belum terjangkau oleh layanan telekomunikasi.

\subsubsection{India}

Tahun 1999, Kabinet menyetujui New Telecom Policy (NTP 99), dengan mendirikan Universal Service Obligation Fund (USOF) dan menetapkan tujuan yang ingin dicapai. Kebijakan Dukungan Layanan Universal berlaku pada tahun 2002. Amendemen UndangUndang Telegraf India (ITR Amandemen) 2003, memberikan status hukum kepada USOF pada tahun 2003. NTP 99 menunjukkan bahwa USOF didirikan hanya untuk tujuan memenuhi layanan universal dengan menyediakan akses ke layanan telepon dasar oleh:
a. Penyediaan layanan telepon dan layanan data kecepatan rendah di pedesaan.
b. Internet akses ke semua ibu kota.
c. Telephone on demand di urban dan rural area.

Pemerintah India melalui Departement of Telecommunication, membuat sebuah badan yang diberi nama Office of Universal Service Fund Administrator (OUSFA), yang memiliki wewenang penuh untuk mengimplementasikan budget yang telah disetujui pemerintah untuk aktifitas USO. Kontribusi pendanaan USOF diperoleh dari adjusted gross revenue sebesar $5 \%$ dari semua operator telekomunikasi dengan tetap adanya 
pendanaan secara terus-menerus dari Pemerintah Pusat dalam bentuk hibah

ataupun pinjaman. Penerima manfaat dari USOF adalah masyarakat di rural dan remote area dimana layanan TIK belum tersedia akibat tidak memiliki nilai komersial. Dibawah inisiatif USOF ini, tiga operator telekomunikasi melakukan sharing passive infrastruktur (tower, lahan, CME, shelter dan lain-lain) yang menempatkan aktif infratrukturnya di titik tersebut

\subsubsection{China}

Pemerintah China pada tahun 2020, setiap rumah memiliki layanan telepon dan setiap desa memiliki akses internet. Sebagai bentuk dukungan, pemerintah memberikan beberapa kebijakan dan kemudahan diantaranya adalah operator yang berinvestasi dalam proyek, yang akan memiliki pasar termasuk jaringan dan pelanggan di daerah yang bersangkutan. Jika operator memiliki kehilangan modal (capital loss), pemerintah akan membayar sejumlah uang per tahun untuk operator sebagai kompensasi kerugian. Selain itu Pemerintah daerah juga memberikan dukungan dan beberapa hak istimewa di bidang perpajakan, Power Supply, tanah dan tenaga kerja, dll

\subsubsection{Canada}

Di Kanada, USO hanya diterapkan untuk layanan teleponi dasar yang dimulai tahun 2000 .

Pendekatan pemerintah Kanada untuk mendukung layanan perdesaan dan daerah terpencil adalah dengan mendanai broadband secara langsung melalui inisiatif pendanaan, daripada melalui subsidi silang melalui pendekatan dana universal. Canadian Radio-television Telecommunications Commission (CRTC) menjadi lembaga yang mengevaluasi program tersebut untuk menentukan keberlanjutan program di masa mendatang.

Pendanaan USO di Kanada didukung oleh Dana Kontribusi Nasional (National Contribution Fund, NCF). Dana tersebut dikumpulkan untuk mensubsidi biaya tinggi layanan untuk penduduk di daerah perdesaan dan terpencil. Kontribusi untuk NCF didasarkan pada pendapatan penyedia layanan telekomunikasi. Regulator, yaitu Canadian RadioTelevision and Telecommunications Commission (CRTC) mengawasi penggunaan dana tersebut.

Kesimpulan:

1. Sampai dengan tulisan ini dibuat, cakupan USO di Indonesia adalah wilayah $3 T$ (Terdepan, Terluat, dan Tertinggal) yang mirip dengan di India, tetapi tidak $100 \%$ sama dengan 
cakupan USO di negara lain, dimana USO mencakup masyarakat yang tidak mampu mambayar langganan internet dimanapun mereka berada - di kota ataupun di desa.

2. Pada kondisi saat ini, Operator Seluler dan Internet Service Provider di Negara Australia, Malaysia, China dan Kanada membangun jaringan di seluruh wilayah negaranya, termasuk di wilayah USO, sehingga tarif internet di daerah USO di negara-negara tersebut (yang dilakukan benchmark) itu tarifnya adalah sama dengan internet di daerah non USO dengan subsidi silang yaitu pungutan USO itu dijadikan subsidi ke operator sebagai pembayaran untuk penggunaan internet dari masyarakat di daerah USO. Di Amerika Serikat, operator wajib membangun wifi gratis di lokasi-lokasi tertentu yang bisa digunakan oleh masyarakat tidak mampu, yang dalam konteks ini di sana merupakan cakupan USO.

3. Pada kondisi saat ini, Operator Seluler dan Internet Service Provider di India dan Indonesia tidak membangun jaringan di wilayah USO, sehingga pemerintah yang membangun jaringan telekomunikasi di wilayah USO.

a. Di India, pembangunan dilakukan oleh Office of Universal Service Fund Administrator (OUSFA). Pembangunan yang dilakukan pemerintah India meliputi penyediaan layanan telepon \& layanan data kecepatan rendah di pedesaan, Internet akses ke semua ibu kota, dan telephone on demand di urban \& rural area. Kontribusi pendanaan untuk membangun diperoleh dari adjusted gross revenue sebesar $5 \%$ dari semua operator telekomunikasi dengan tetap adanya pendanaan secara terus-menerus dari Pemerintah Pusat dalam bentuk hibah ataupun pinjaman.

b. Di Indonesia, tetapi kontribusi pendanaan USO oleh operator dan service provider di Indonesia sebesar 1,25\% adalah jauh lebih kecil daripada di India yang seesar $5 \%$. Sebagian besar daerah USO di Indonesia masuk dalam wilayah $3 \mathrm{~T}$. Pemerintah Indonesia, melalui BAKTI KOMINFO membangun jaringan telekomunikasi yang meliputi Palapa Ring, BTS, dan Akses Internet serta SATRIA (Satelit Republik Indonesia) yang in-progress. Selain membutuhkan biaya yang besar untuk membangun jaringan telekomunikasi di wilayah 3T, BAKTI juga membutuhkan dana yang besar untuk memsubsidi masyarakat 3T agar bisa memanfaatkan jaringan yang sudah dibangun.

\section{References}

[1] Colin Blackman; Lara Srivastava. (2018). Telecommunications Regulation Handbook Tenth Anniversary Edition. The International Bank for Reconstruction and Development \& InfoDev - The World Bank. Available at http://www.infodev.org/infodevfiles/resource/InfodevDocuments 1057.pdf

[2] ICT Regulation Toolkit. (2018). Universal Access.

Available at http://www.ictregulationtoolkit.org/toolkit/1.5

[3] Denny Setiawan. (2018). Regulasi dan kebijakan Telekomunikasi di Indonesia. Available di http://denysetia.wordpress.com/regulasi-spektrum-frekuensi-radioindonesia/regulasispektrum-frekuensi-radio-di-indonesia/kajian-kebijakan-dan-regulasifrekuensi/

[4] Harashta Tatimma Larasati; Sigit Haryadi. (2016). Basic planning of data center infrastructure and bandwidth requirement in integrated government network. 2nd International Conference on Wireless and Telematics (ICWT), in Yogyakarta, Indonesia.

[5] Haryadi, S. (2013). Telecommunication Service and Experience Quality. Lantip Safari Media, Bandung, Indonesia. ISBN: 978-602-18578-6-1. 
[6] Haryadi, S. (2013). Telecommunication Traffic: Technical and Business Consideration. Lantip Safari Media, Bandung, Indonesia. ISBN: 978-602-18578-5-4.

[7] Haryadi, S. (2017). Calculation of the Mobile Communication Competition using Haryadi Index. DOI10.13140/RG.2.2.15634.25280

[8] Haryadi, S. (2017). Catatan Kuliah "Overview Organisasi Regulasi Telekomunikasi". DOI10.13140/RG.2.2.34928.05122.

[9] Haryadi, S. (2017). Catatan Kuliah Ekonomi Bisnis Regulasi dan Kebijakan Telekomunikasi: Prinsip - Prinsip Ilmu Ekonomi \& Perbankan. Researchgate. DOI10.13140/RG.2.2.29894.88648.

[10] Haryadi, S. (2017). Catatan Kuliah Lisensi Provider dan Operator Telekomunikasi. DOI10.13140/RG.2.2.13117.67046

[11] Haryadi, S. (2017). Chapter 9 Universal Access and Services Regulation Telecommunication Economy, Business, Regulations and Policy". Researchgate. DOI10.13140/RG.2.2.31572.60804.

[12] Haryadi, S. (2017). Ekonomi Bisnis Regulasi dan Kebijakan Telekomunikasi: PrinsipPrinsip Ilmu Hukum. DOI10.13140/RG.2.2.30524.03207.

[13] Haryadi, S. (2017). Ekonomi Bisnis Regulasi dan Kebijakan Telekomunikasi: Prinsip Penyusunan Kebijakan Negara. DOI10.13140/RG.2.2.17102.25927.

[14] Haryadi, S. (2017). Ekonomi, Bisnis, Regulasi dan Kebijakan Telekomunikasi, Bab 6. Overview Organisasi Regulasi Telekomunikasi. DOI10.13140/RG.2.2.34928.05122.

[15] Haryadi, S. (2017). Lecture Note "Telecommunication Interconnection". DOI10.13140/RG.2.2.21506.2784.

[16] Haryadi, S. (2017). Tren Global pada Bisnis \& Teknologi Telekomunikasi. DOI10.13140/RG.2.2.27168.58883.

[17] Haryadi, S. (2018, February 22). Kalkulator Untuk Menghitung Korelasi Kesetaraan. Retrieved from osf.io/preprints/inarxiv/7r9jy

[18] Haryadi, S. (2018, February 28). Ikhtisar Organisasi Regulasi Telekomunikasi. Retrieved from osf.io/preprints/inarxiv/g9m3k

[19] Haryadi, S. (2018, February 6). Prinsip - Prinsip Penyusunan Kebijakan Negara di Bidang Telekomunikasi. Retrieved from osf.io/32g65

[20] Haryadi, S. (2018, February 7). Statistik Terapan: Pengujian Regulasi \& Kebijakan Telekomunikasi. Retrieved from osf.io/3pkfw

[21] Haryadi, S. (2018, February). Applied Statistics for Assessment of the Regulation and Policy: case study in Telecommunication Industry. DOI10.13140/RG.2.2.15774.02884

[22] Haryadi, S. (2018, January 17). Bab 1. Tren Global Pada Bisnis \& Teknologi Telekomunikasi. Retrieved from https://osf.io/fvcha

[23] Haryadi, S. (2018, January 19). Catatan Kuliah Ekonomi, Bisnis, Regulasi dan Kebijakan Telekomunikasi Bab 2 semester 2 Tahun 2017/2018: Prinsip-Prinsip Ilmu Hukum. Retrieved from https://osf.io/3c9n4

[24] Haryadi, S. (2018, January 29). Bab 4 dari buku "Ekonomi Bisnis Regulasi dan Kebijakan Telekomunikasi”: Prinsip - Prinsip Ilmu Ekonomi \& Perbankan. Retrieved from https://osf.io/az9ye

[25] Haryadi, S. (2018, March 1). Kebijakan Lisensi Telekomunikasi. Retrieved from osf.io/7wbjf

[26] Haryadi, S. (2018, March 3). Telecommunication Pricing Regulation Theory and Problem Solution Examples. Retrieved from osf.io/5wr7k

[27] Haryadi, S. (2018, March 5). Performance Measurement of Internet Service. Retrieved from osf.io/9nsw3

[28] Haryadi, S. (December 2017). Calculator for Measurement the Competition Index \& Level. Researchgate. DOI 10.13140/RG.2.2.23626.26568 
Haryadi, S., \& Riani, W. (2018, March 5). METODE PENETAPAN TARIF PAJAK PENGHASILAN YANG BERKEADILAN. Retrieved from osf.io/preprints/inarxiv/ayg58 [29]

[30] Homepage of The International Telecommunication Union: https://www.itu.int/en/Pages/default.aspx

[31] Link "Regulasi" dari Direktorat Jenderal Sumber Daya dan Perangkat Pos dan Informatika, Indonesia di: http://www.postel.go.id/

[32] Wikipedia, the free encyclopedia. (12 January 2018). Broadband universal service. Available online at https://en.wikipedia.org/wiki/Broadband universal service.

[33] Windi Rahma Agustin; Sigit Haryadi. (2017). Sustainability of Indonesian Telecommunication Operators in the Era of Net Neutrality. 3rd International Conference on Wireless and Telematics (ICWT), July 2017 in Palembang, Indonesia. 
